\title{
HUBUNGAN KADAR ASAM URAT SERUM DENGAN KADAR HIGH- SENSITIVITY C-REACTIVE PROTEIN PADA REMAJA OBES
}

\author{
${ }^{1}$ Agustinus Mahardhika Sarayar \\ ${ }^{2}$ Murniati Tiho \\ ${ }^{2}$ Yanti Mewo
}

\author{
1. Kandidat Skripsi Fakultas Kedokteran Universitas Sam Ratulangi \\ 2. Bagian Biokimia Fakultas Kedokteran Universitas Sam Ratulangi \\ Email: sarayar.agusinus@gmail.com
}

\begin{abstract}
Uric acid has low water solubility. When the concentration exceeds its solubility, it will form monosodium urate (MSU) crystals which can trigger inflammation. High sensitivity Creactive protein (hs-CRP) is one of the most liable inflammatory biomarker and recently considered as major modifiable risk factor of coronary heart disease. Serum uric acid and hs-CRP levels are often elevated in obese patients. The purpose of this study are to determine hs-CRP and serum uric acid levels and to determine the correlation between serum uric acid and hs-CRP levels in obese adolescents. This is an analytic observational study with cross sectional design. Subject consist of 17 obese adolescents age 17-20 years with percentile of $\geq 95$ in CDC BMI-forage chart. Nonparametric analysis with Spearman test was applied to find the correlation between serum uric acid and hs-CRP levels. The mean serum uric acid and hs-CRP levels in obese subjects were 7.37 (SD 1.66) $\mathrm{mg} / \mathrm{dL}$ and 1.73 (SD 1.44) $\mathrm{mg} / \mathrm{L}$ respectively. In conclusion, a statistically insignificant correlation between serum uric acid and hs-CRP levels was found ( $\mathrm{p}=$ $0.296, r=0.14)$. Serum uric acid levels are consistently higher in obese adolescents. Hs-CRP levels among obese subject shows moderate risk of developing cardiovascular disease in the future.
\end{abstract}

Keywords: Adolescents, hs-CRP, obese, serum uric acid

\begin{abstract}
Abstrak: Asam urat memiliki kelarutan yang rendah dalam air. Saat konsentrasi asam urat melebihi batas ambang solubilitas, akan terbentuk kristal monosodium urat yang akan memicu inflamasi. High sensitivity C-reactive protein (hs-CRP) merupakan salah satu biomarker inflamasi yang belakangan ini dijadikan faktor risiko mayor yang dapat dimodifikasi dari penyakit jantung koroner. Kadar asam urat serum dan hs-CRP biasanya meningkat pada penderita obesitas. Tujuan dari penelitian ini untuk mengetahui hubungan kadar asam urat serum dengan hs-CRP serta gambaran kadar asam urat serum dan hs-CRP pada remaja obes. Penelitian ini menggunakan desain penelitian analitik observasional dengan pendekatan cross-sectional. Subjek terdiri dari 17 remaja obes usia 17-20 tahun dengan persenti 95 pada grafik IMT terhadap usia CDC. Analisis data menggunakan Spearman test digunakan untuk mengetahui korelasi antara kadar asam urat serum dengan hs-CRP. Nilai rata-rata kadar asam urat serum dan hs-CRP yang didapat secara berurutan mencapai 7,37 (SD 1,66) mg/dL dan 1,73 (SD 1,44) mg/L. Sebagai kesimpulan, hubungan kadar asam urat serum dengan hs-CRP tidak signifikan ( $\mathrm{p}=$ $0,296)$ dan berkorelasi positif lemah $(r=0,14)$. Kadar asam urat serum pada remaja obes tergolong tinggi. Kadar hs-CRP remaja obes termasuk dalam risiko menengah untuk terkena penyakit kardiovaskular di masa mendatang.
\end{abstract}

Kata kunci: Asam urat serum, hs-CRP, Obesitas, Remaja 
Obesitas merupakan keadaaan ketika terjadi akumulasi lemak abnormal atau berlebihan yang menghadirkan risiko bagi kesehatan. ${ }^{1}$ Setelah dianggap sebagai masalah hanya di negara berpenghasilan tinggi, berat badan berlebih dan obesitas secara dramatis meningkat di negara berpenghasilan rendah dan menengah, khususnya di perkotaan. ${ }^{1,2}$ Berdasarkan Riset Kesehatan Dasar (RISKESDAS) nasional tahun 2010, Sulawesi Utara memiliki prevalensi obesitas tertinggi (37,1\%) dibandingkan dengan propinsi lain di Indonesia. ${ }^{2}$ Obesitas merupakan salah satu faktor risiko tingginya kadar asam urat (hiperurisemia). ${ }^{3}$

Dalam darah, asam urat mayoritas berbentuk garam. Konsentrasi rata-rata asam urat dalam darah mendekati batas ambang solubilitas yaitu $6,8 \mathrm{mg} / \mathrm{dL}^{4,5}$ sehingga peningkatan sedikit konsentrasi asam urat akan melewati batas ambang solubilitasnya. ${ }^{6}$ Kadar asam urat yang meningkat (> 6,8 $\mathrm{mg} / \mathrm{dL}$ ) akan membentuk banyak kristal asam urat berupa kristal monosodium urate (MSU) yang dapat menstimulasi inflamasi pada gout dan juga penyakit yang berhubungan dengan inflamasi lain, diantaranya penyakit kardiovaskular. Hiperurisemia merupakan faktor risiko penyakit kardiovaskular baru. ${ }^{7}$ Bahkan dalam National Health and Nutrition Survey (NHANES I Study), kadar asam urat serum sudah merupakan faktor risiko independen penyakit kardiovaskular pada lelaki dan perempuan. $^{8}$

Peningkatan kadar hs-CRP
digunakan sebagai inflamasi $^{9}$ dan faktor risiko penyakit kardiovaskular. ${ }^{9,10}$ Penelitian ini dilakukan untuk mencari hubungan antara peningkatan kadar asam urat serum dengan peningkatan kadar hs-CRP sebagai penanda inflamasi kronis yang merupakan dasar aterosklerosis, penyakit jantung, dan penyakit lain dengan dasar inflamasi pada remaja obes usia 17-20 tahun.

\section{METODE PENELITIAN}

Penelitian ini menggunakan desain penelitian analitik observasional dengan pendekatan cross sectional. Penelitian ini dilakukan terhadap 17 orang mahasiswa Fakultas Kedokteran Universitas Sam Ratulangi dengan usia 17-20 tahun di angkatan 2011, 2012, dan 2013 yang tergolong obes. Obesitas diklasifikasikan berdasarkan grafik IMT terhadap usia CDC tahun 2000, dengan persentil $\geq 95$ termasuk dalam kategori obes. Mahasiswa yang mengikuti penelitian hanya yang dalam kondisi sehat dan tidak menggunakan obatobatan yang dapat mempengaruhi kadar asam urat serum dan hs-CRP pada periode pengambilan sampel. Sebelum pengambilan sampel yang dilakukan oleh petugas laboratorium, responden diminta menandatangani informed consent dan diwajibkan untuk berpuasa selama 12-14 jam.

Kadar asam urat serum diukur di laboratorium dengan menggunakan metode Enzymatic Calorimetri/ Uricase. Kadar asam urat $>7 \mathrm{mg} / \mathrm{dL}$ pada lelaki dan $>6$ $\mathrm{mg} / \mathrm{dL}$ pada perempuan digolongkan sebagai hiperurisemia. Kadar hs-CRP didapat dengan cara pemeriksaan CRP menggunakan metode ECLIA dengan unit reagen Roche Diagnostic dan alat Cobas e601, hsCRP dapat diperiksa secara kuantitatif dari darah vena. Kategori risiko penyakit kardiovaskular menurut kadar hsCRP dibagi menjadi tiga, yaitu risiko rendah, menengah, dan tinggi (Tabel 1). ${ }^{11}$

Tabel 1. Kategori Risiko Penyakit Kardiovaskular Menurut Kadar hs-CRP ${ }^{11}$

\begin{tabular}{cl}
\hline Kadar hs-CRP & Kategori \\
\hline$<1,0 \mathrm{mg} / \mathrm{L}$ & Risiko rendah \\
$1,0-3,0 \mathrm{mg} / \mathrm{L}$ & Risiko menengah \\
$>3,0 \mathrm{mg} / \mathrm{L}$ & Risiko tinggi \\
\hline
\end{tabular}


Analisis univariat dilakukan untuk mengetahui deskripsi data yang diperoleh dari kadar asam urat serum dan kadar hsCRP penderita Obes. Analisis bivariat menggunakan Statistical Package for the Social Sciences (SPSS) dilakukan untuk melihat hubungan antara kadar asam urat serum dengan kadar hs-CRP mahasiswa obes menggunakan analisis korelasi Spearman.

\section{HASIL PENELITIAN}

Subjek penelitian sebanyak 17 orang terdiri dari 11 remaja laki-laki (64,7\%) dan 6 remaja perempuan (35,3\%). Berdasarkan usia diketahui, subjek yang paling banyak merupakan responden yang berusia 17 tahun dengan jumlah 8 responden $(47,1 \%)$. Responden yang berusia 18 tahun berjumlah 7 orang (41,2\%). Responden yang berusia 19 tahun dan 20 tahun masing-masing berjumlah 1 orang (5,9\%). Rata-rata usia subjek 17 tahun delapan bulan.

Nilai rata-rata kadar asam urat serum responden mencapai 7,365 mg/dL, dengan nilai rata-rata kelompok pria mencapai 7,93 $\mathrm{mg} / \mathrm{dL}$ dan 6,33 mg/dL untuk perempuan. Nilai minimum dan maksimum kadar asam urat serum secara berurutan adalah 4,6 mg/dL dan 11,8 mg/dL. Nilai tengah kadar asam urat responden adalah $7,2 \mathrm{mg} / \mathrm{dL}$ dengan nilai standar deviasi sebesar 1,66 mg/dL (Tabel 2). Berdasarkan batasan hiperurisemia yang dibuat oleh WHO dan diikuti oleh Perhimpunan Dokter Spesialis Penyakit Dalam Indonesia, yaitu $>7 \mathrm{mg} / \mathrm{dL}$ untuk lelaki dan > 6mg/dL untuk perempuan, sebanyak 11 responden yang terdiri dari delapan lelaki dan tiga perempuan tergolong hiperurisemia.

Nilai rata-rata hs-CRP responden adalah $1,729 \mathrm{mg} / \mathrm{L}$ dengan nilai minimum sebesar $0,2 \mathrm{mg} / \mathrm{L}$ dan nilai maksimum sebesar 5,0 mg/L (Tabel 2). Merujuk pada klasifikasi kadar hs-CRP sebagai faktor risiko penyakit kardiovaskular yang dibuat oleh American Heart Association, enam orang memiliki risiko rendah (kadar hs-CRP $<1 \mathrm{mg} / \mathrm{L}$ ), sembilan orang memiliki risiko menengah (kadar hs-CRP 1-3 mg/L), dan dua orang termasuk dalam kelompok berisiko tinggi (kadar hs-CRP $>3 \mathrm{mg} / \mathrm{L}$ ) terkena penyakit kardiovaskular.

Tabel 2. Distribusi Kadar Asam Urat Serum dan hs-CRP

\begin{tabular}{lcc}
\hline & $\begin{array}{c}\text { Asam } \\
\text { urat } \\
\text { serum }\end{array}$ & hsCRP \\
\hline $\mathrm{N} \quad$ Valid & 17 & 17 \\
Mean & 7.365 & 1.729 \\
Median & 7.2 & 1.3 \\
Std. Deviation & 1.6606 & 1.4443 \\
Minimum & 4.6 & 0.2 \\
Maximum & 11.8 & 5 \\
\hline
\end{tabular}

Langkah pertama yang dilakukan untuk melakukan analisis bivariat yaitu melakukan uji normalitas data dengan menggunakan uji Shapiro-Wilk. Uji normalitas Shaphiro-Wilk dipilih karena jumlah sampel penelitian kurang dari 50 . Uji normalitas Shaphiro-Wilk pada kadar asam urat serum menunjukkan data kadar asam urat serum terdistribusi secara normal, tetapi data kadar hs-CRP tidak terdistribusi normal. Data hs-CRP yang memiliki distribusi tidak normal merupakan dasar untuk dilakukan uji nonparametrik Spearman untuk melihat hubungan kadar asam urat serum dengan kadar hs-CRP.

Berdasarkan data hasil laboratorium, uji nonparametrik Spearman mendapatkan nilai koefisien korelasi $(r)=0,14$ dan nilai signifikansi $(\rho)=0,296$ yang lebih besar dari $\alpha 0,05$ (Tabel 3). Hal ini menunjukkan bahwa kadar asam urat serum dengan kadar hs-CRP pada remaja obes memiliki hubungan yang tidak signifikan. Koefisien korelasi berada dalam rentang $0,1-0,3$ yang berarti bahwa kadar asam urat serum dengan kadar hs-CRP memiliki korelasi positif yang lemah. 
Tabel 3. Korelasi Kadar Asam Urat Serum Dengan Kadar hs-CRP

\begin{tabular}{ll}
\hline & Kadar Asam Urat Serum \\
\hline hs-CRP & $r=0,14$ \\
& $p=0,296$ \\
\hline
\end{tabular}

\section{BAHASAN}

Sebanyak 11 dari 17 responden (64,7\%) mengalami hiperurisemia. Distribusi berdasarkan jenis kelamin mendapatkan delapan dari 11 (72,73\%) lelaki dan tiga dari enam (50\%) perempuan memililki kadar asam urat di atas normal. Nilai Prevalensi hiperurisemia hasil penelitian ini lebih tinggi dibandingkan beberapa penelitian yang pernah dilakukan mengenai hiperurisemia dengan subjek penderita obes.

Pada studi dengan subjek anak dengan berat badan berlebih dan obesitas yang dilakukan di Spanyol oleh Modino et al, didapatkan prevalensi hiperurisemia mencapai 53\%. ${ }^{12}$ Studi lain dengan karakteristik subjek yang sama dengan usia 6-14 tahun yang dilakukan oleh Tang L et al di Jepang mendapatkan prevalensi hiperurisemia hanya mencapai $20,7 \%{ }^{13}$, jauh lebih rendah dari hasil penelitian yang didapat. Ada kecenderungan prevalensi hiperurisemia lebih tinggi pada remaja obes di Manado. Hal ini dapat disebabkan oleh lingkungan, konsumsi makanan, dan keadaan genetik responden.

Nilai rata-rata kadar hs-CRP responden pada penelitian ini mencapai 1,729 mg/L. Nilai rata-rata kadar hs-CRP dalam penelitian ini lebih tinggi dari nilai rata-rata kadar hs-CRP pada penelitian yang dilakukan oleh El-shorbagy $\mathrm{HH}$ et al dengan subjek anak dan remaja obes usia 6-16 yang mencapai $1,4 \mathrm{mg} / \mathrm{L}^{14}$ Selain itu, nilai rata-rata kadar hs-CRP responden dalam penelitian ini lebih tinggi dari kadar hs-CRP penelitian yang dilakukan oleh Elshorbagy $\mathrm{HH}$ et al pada kelompok kontrol (nonobes) dengan nilai rata-rata 0,56 mg/L. ${ }^{14}$ Peningkatan kadar hs-CRP pada remaja obes ini juga sejalan dengan penelitian yang dilakukan oleh Harun dkk di Makassar pada tahun 2013. ${ }^{15}$

Sel lemak (adiposit) dan sel-sel preadiposit sudah diidentifikasikan sebagai sumber sitokin-sitokin proinflamasi, termasuk tumor necrosis factor- $\alpha$ (TNF$\alpha$ ), interleukin 1 (IL-1), dan interleukin 6 (IL-6). Oleh karena itu, obesitas menyebabkan terjadinya keadaan inflamasi kronis. ${ }^{16}$ Interleukin 6 yang merupakan salah satu sitokin yang memiliki banyak efek dalam mekanisme pertahanan dan inflamasi, dapat diproduksi oleh makrofag dan sel endotel. ${ }^{16}$ Selain itu, Nishimura et al mengajukan bahwa jaringan lemak pada penderita obes mengaktifkan efektor CD8+ sel T, yang kemudian mempromosi rekruitmen dan aktivasi makrofag dalam jaringan ini. ${ }^{17}$

Berdasarkan hasil uji statistik dengan menggunakan uji nonparametrik Spearman, kadar asam urat serum memiliki hubungan yang tidak signifikan dan korelasi positif yang lemah dengan kadar hs-CRP pada remaja obes. Nilai tengah kadar hs-CRP yang didapat pada penelitian ini yang mencapai $1,3 \mathrm{mg} / \mathrm{L}$ hampir sama dengan nilai yang didapat oleh peneliti Wasilewska et al pada subjek anak obes penderita hiperurisemia $(1,18$ $\mathrm{mg} / \mathrm{L}) .^{18}$ Meskipun demikian, hubungan hasil yang didapat peneliti berbeda dengan yang didapat oleh Wasilewska et al. Data hs-CRP pada penelitian Wasilewska secara signifikan lebih tinggi dibanding nilai tengah dari kelompok kontrol (nonobes dan tidak hiperurisemia) dalam studi yang sama, yaitu $0,24 \mathrm{mg} / \mathrm{L}$. Anak dan remaja penderita hiperurisemia memiliki kadar hs-CRP yang sedikit lebih tinggi dibanding kelompok kontrol yang sehat, yaitu $0,53 \mathrm{mg} / \mathrm{L}^{18}$

Berbagai studi eksperimental membuktikan bahwa asam urat dapat menstimulasi reaksi inflamasi. ${ }^{18}$ Ketika kadar asam urat serum meningkat, sebagian asam urat ini masuk ke dalam sel otot polos pembuluh darah dan akan terjadi inflamasi dengan peningkatan kadar hs-CRP sebagai penanda. ${ }^{18}$ 
Berlawanan dengan beberapa penelitian yang pernah dilakukan, hasil yang didapatkan peneliti menyatakan bahwa hubungan antara peningkatan kadar asam urat serum tidak berhubungan secara signifikan terhadap peningkatan hs-CRP secara langsung pada remaja obes.

Penelitian yang dilakukan oleh penulis ini memiliki kekurangan, yakni jumlah responden penelitian yang hanya mencapai $70 \%$ dari seluruh populasi yang ada serta jumlah responden perempuan yang lebih sedikit dari responden laki-laki.

\section{KESIMPULAN}

Berdasarkan hasil penelitian yang telah dilakukan, penulis menyimpulkan bahwa remaja obes memiliki kadar asam urat serum yang tinggi dan kadar hs-CRP yang termasuk dalam kategori risiko menengah. Tidak terdapat hubungan antara kadar asam urat serum dengan kadar hs-CRP pada remaja obes.

\section{DAFTAR PUSTAKA}

1. World Health Organization Regional Office for South East Asia. Overweight and Obesity. Department of Sustainable Development and Healthy Environments. [homepage on the Internet]. 2011. [cited 2013 October 15] available from: http://www.searo.who.int/entity/noncom municable_diseases/media/non_communi cable_diseases_obesity_fs.pdf

2. Departemen Kesehatan Republik Indonesia. . Badan Litbang Kesehatan. Riset Kesehatan Dasar Nasional. Jakarta: Departemen Kesehatan R.I.; 2010.

3. Anonimous. Evaluation and Management of Obesity: Introduction. In: Longo DL, Kasper DL, Jameson JL, Fauci AS, Hause SL, Loscalzo J, editors. Harrison's Principles of Internal Medicine $\left(18^{\text {th }}\right.$ Edition). McGraw-Hill Companies, Inc, 2012; p. 1622-32.

4. Anonimous. Disorders of Purine and Pyrimidine Metabolism. In: Longo DL, Kasper DL, Jameson JL, Fauci AS, Hause SL, Loscalzo J, editors. Harrison's Principles of Internal Medicine $\left(18^{\text {th }}\right.$
Edition). McGraw-Hill Companies, Inc, 2012; p. 6129-41.

5. Rodwell VW. Metabolism of Purine \& Pyrimidine Nucleotides. Murray RK, Bender DA, Botham KM, Kennelly PJ, Rodwell VW, Weil PA, editor. In Harper's Illustrated Biochemistry (28 ${ }^{\text {th }}$ Edition). China: The McGraw-Hill Companies, Inc, 2009; 33: 292-301.

6. Meisenberg G, Simmons WH. Principles of Medical Biochemistry ( ${ }^{\text {rd }}$ Edition). Philadelphia: Elsevier Saunders Inc, 2012; 28: 471-80.

7. Kawai T, Ohishi M, Takeya Y, Onishi M, Ito N, Yamamoto K, et al. Serum uric acid is an independent risk factor for cardiovascular disease and mortality in hypertensive patients. Hypertension Research [serial online]. 2012. [cited 2013 Okt 13]; 35: 1087-1092. available from:

http://www.nature.com/hr/journal/v35/n1 1/full/hr201299a.html

8. Kubota M, Nagai A, Tang L, Tokuda M. Investigation on Hyperuricemia in Children with Obesity or Various Pediatric Disorders. Nucleosides, Nucleotides and Nucleic Acids. Taylor and Francis Group, 2011; 30(12): 105159.

9. Pincus MR, Abraham NZ. Interpreting Laboratory Results. In: Lifshitz MS, Pincus MR, Threatte A, editor. In: McPherson \& Pincus: Henry's Clinical Diagnosis and Management by Laboratory Methods (21 ${ }^{\text {st }}$ Edition). Elsevier Inc; 2007.

10. McPherson RA. Specific Proteins. In: Lifshitz MS, Pincus MR, Threatte A, editor. In: McPherson \& Pincus: Henry's Clinical Diagnosis and Management by Laboratory Methods (21 ${ }^{\text {st }}$ Edition). Elsevier Inc; 2007.

11. Wilson DD. Mc Graw-Hill's Manual of Laboratory \& Diagnostic Tests. McGrawHill Companies, Inc, 2008; p. 191-192.

12. Modino SC, Armas MGG, Mejías SM, Martínez JMM, Bolañosa PI, Viveros MM, et al. Hyperuricemia and metabolic syndrome in children with overweight and obesity Endocrinología y Nutrición, 2012; 59(9): 533-538 available at http://www.sciencedirect.com/science/arti cle/pii/S2173509312001729 
13. Tang L, Kubota M, Tokuda $M$. Hyperuricemia in obese children and adolescents: the relationship with metabolic syndrome. Pediatr Rep, 2010; 2(1): e12. Available at http://www.ncbi.nlm.nih.gov/pmc/articles /PMC3094014/

14. El-Shorbagy HH, Ghoname IA. High sensitivity C-reactive protein as a marker of cardiovascular risk in obese children and adolescents. Health, 2010; 10: 107884.

15. Harun I, Hadju V, Taslim NA. Obesitas dan hsCRP pada remaja mahasiswa baru di Universitas Hasannudin. [cited 2 Februari 2014] Available from: pasca.unhas.ac.id
16. Sanchez AF, Santillan EM, Bautista M, Soto JE, Gonzales AM, Chirino CE et al. Inflammation, oxidative stress, and obesity. Int J Mol Sci, 2011; 12: 3117-32.

17. Nishimura $S$, Manabe I, Nagasaki $M$, Eto K, Yamashita $H$, Ohsugi M, et al. CD 8+ Effector $\mathrm{T}$ Cells contribute to Macrophage Recriutment and Adipose Tissue Inflammation in Obesity. Nat Med, 2009; 15(8): 914-20. Available at http://www.ncbi.nlm.nih.gov/pubmed/196 33658

18. Wasilewska A, Tenderenda E, TarantaJanusz K, Tobolczyk J, Stypulkowska J. Markers of Inflammation in Children with Hyperuricemia. Acta Pediatrica, 2012; 101(5): 497-500. 